\title{
PENERAPAN OKALA ECO-DESIGN STRATEGY WHEEL PADA PROYEK DESAIN MAHASISWA PRODUCT DESIGN ENGINEERING
}

\author{
${ }^{1}$ Pierre Yohanes Lubis, ${ }^{2}$ Mariano Ramirez \\ ${ }^{1}$ Product Design Engineering Department, BINUS ASO School of Engineering, BINUS University, Jl. Alam Sutera \\ Boulevard No. 1, Alam Sutera, Serpong, Pakulonan, Tangerang \\ ${ }^{2}$ Industrial Design, Faculty of Built Environment, University of New South Wales, Australia, Australia West Wing \\ Red Centre Building Kensington Campus \\ e-mail: pierre.yohanes.lubis@gmail.com
}

\begin{abstract}
Abstrak
Pengajaran desain produk industri yang berbasis keberlanjutan (sustainable product design) adalah aspek pendidikan desain produk industri yang penting dalam pendidikan desain pada umumnya saat ini. Penelitian ini ditujukan untuk memberi pemahaman lebih lanjut mengenai desain produk industri yang berkelanjutan dalam lingkup perguruan tinggi dengan menerapkan metode Okala pada proyek desain mahasiswa Product Design Engineering untuk memperoleh desain-desain yang berkelanjutan dan yang lebih berwawasan lingkungan. Okala Eco-Design Strategy Wheel merupakan metode life cycle assessment yang memberikan pandangan lebih luas bagi desainer produk industri untuk sehingga dapat memperkirakan dampak yang mungkin terjadi dalam masa hidup sebuah produk mulai dari pembuatan hingga saat produk tersebut habis masa pakai/siklus hidupnya. Hasil penelitian ini menunjukkan bahwa metodologi Okala dapat secara cepat dipahami dan dengan waktu yang cukup singkat diterapkan oleh mahasiswa pada proyek desain mereka. Dengan demikian, dalam garis besarnya, metode Okala dinilai dapat memberikan pemahaman lebih kepada mahasiswa khususnya terkait dengan topik desain produk industri yang berkelanjutan.
\end{abstract}

Kata Kunci : Ecodesign; life cycle assessment; sustainable product design; desain produk berkelanjutan; pendidikan desain produk industri

\section{PENDAHULUAN}

Pada tahun 2001, para desainer produk yang tergabung dalam ICSID (International Council of Societies of Industrial Design) mendeklarasikan komitmen untuk tidak lagi memandang lingkungan sebagai sebuah entitas yang terpisah dan berusaha untuk mewujudkan jalur perkembangan yang berkelanjutan (ICSID, 2001). Hal ini juga tertuang dalam kode etik desainer internasional pada tahun 1987 bahwa tiap desainer harus mengemban tanggung jawab dalam tindakan yang mengutamakan ekologi dan berwawasan lingkungan (ICSID, 1987). Hal ini juga dikemukakan oleh Findeli (2001), bahwa para desainer yang bertanggung-jawab (responsible designers) pasti akan menghasilkan produk-produk yang bertanggung jawab (responsible products) pula. Dapat dikatakan bahwa inisiatif ini adalah jawaban untuk Papanek (1971) yang mengecam keras profesi desainer produk sebagai salah satu profesi yang paling destruktif diantara profesi-profesi yang ada. Bagi kalangan responsible designers, pemahaman akan pentingnya ekologi dan lingkungan serta tantangan untuk menjadikan keseluruhan kegiatan perancangan menjadi kegiatan yang berkelanjutan merupakan topik yang sangat mendasar (Park, 2010).

Dari penelitian singkat penulis, saat ini tidak ada cukup penekanan aspek berkelanjutan dalam pendidikan desain produk industri di Indonesia, terlepas dari satu universitas yang memiliki mata kuliah desain produk berkelanjutan dalam kurikulumnya. Apabila dibandingkan dengan Australia, mayoritas program studi desain produk di universitas-universitas Australia dimana aspek keberlanjutan (sustainability) cukup mendominasi dalam kurikulumnya (Ramirez, 2005). Ramirez (2007) telah melakukan survei mengenai aspek keberlanjutan pada programprogram desain produk di universitas-universitas pada skala global dan menemukan bahwa bahkan ada beberapa universitas yang melabel programnya dengan istilah Sustainable Product Design. Dengan semangat yang serupa, sudah sepatutnya pendidikan desain produk industri, terlebih di Indonesia, mengemban tugas yang sama yaitu mengintegrasikan aspek desain produk yang berkelanjutan dalam pendidikan desain produk industri di Indonesia. 
Dari kondisi permasalahan yang diuraikan di atas, perlu diselidiki apakah metode Okala sebagai salah satu perangkat perancangan dapat menjadi perangkat yang efektif untuk mengembangkan pengajaran aspek keberlanjutan dalam pendidikan desain produk industri di Indonesia.

\section{METODE PENELITIAN}

Metode penelitian ini menggunakan cara eksperimen singkat dan workshop. Beberapa metode life cycle assessment yang tersedia saat ini, antara lain Gabi, SimaPro, Autodesk Eco Material Advisor Solidworks Sustainability plug-in dipertimbangkan untuk dijadikan sebagai tool dalam workshop. Akan tetapi, metode Okala akhirnya dipilih mengingat keuntungannya sendiri sehingga bisa diintegrasikan pada tahapan awal desain. Dengan demikian, seorang desainer produk dengan menggunakan metode Okala, sudah dapat memperkirakan dampak yang akan ditimbulkan produk yang akan didesain sebelum proses desain betul-betul dimulai dan disaat proses produksi pun belum mulai dicanangkan. Oleh karena itu, metode Okala dinilai sesuai untuk diterapkan dalam workshop ini.

Metode yang digunakan dalam penelitian ini menggunakan perangkat Okala Ecodesign Strategy Wheel. Perangkat sistematis ini merupakan perangkat yang dapat membantu desainer produk industri dalam proses perancangan produk, jasa dan sistem dengan tujuan memberikan dampak buruk minimum pada ekologi dan manusia pada waktu yang bersamaan.

\section{A. Okala Ecodesign Strategy Wheel}

Okala merupakan metode life cycle assessment yang memberikan pandangan lebih luas bagi berbagai tim desain untuk memahami siklus hidup produk sehingga dapat memperkirakan dampak yang mungkin terjadi dalam kurun waktu sebuah produk berlangsung. Okala pertama kali diperkenalkan pada tahun 2003 dan didistribusikan melalui IDSA (Industrial Designers Society of America) melalui pendanaan oleh Whirlpool, Eastman Chemical, Environmental Protection Agency dan IDSA. Okala diciptakan oleh Phillip White, Louise St. Pierre dan Steve Belletire. Ketiganya merupakan desainer produk industri dan pengajar di berbagai universitas.

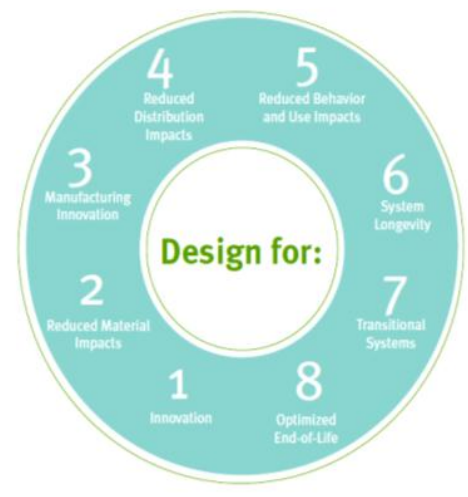

Gambar 1. Okala, the ecodesign strategy wheel

Sumber: http://www.okala.net/downloadapp.html

\section{B. Pelaksanaan Workshop Okala}

Workshop dilakukan pada tanggal 8 Mei 2017 di ruangan 207 di BINUS ASO School of Engineering (BINUS University), kampus Alam Sutra, Tangerang dengan partisipasi 9 orang mahasiswa semester 4 dari program sarjana Product Design Engineering. Eksperimen dilakukan dalam lingkup dan kurun waktu mata kuliah Image Manipulation Technique I yang dikelola oleh penulis utama selaku dosen yang bertanggung jawab atas mata kuliah tersebut dengan panduan dari penulis kedua. Berikut adalah susunan acara pelaksanaannya. 
Tabel 1. Susunan acara pelaksanaan workshop

\begin{tabular}{cl}
\hline Waktu & \multicolumn{1}{c}{ Kegiatan } \\
\hline & $\begin{array}{l}\text { Masing-masing mahasiswa mempresentasikan } \\
\text { proyek desain botol parfum mereka melalui }\end{array}$ \\
medium presentasi, poster dan model/mockup \\
dan prototype. Bentuk proyek desain adalah \\
perseorangan (individual project), bukan \\
kelompok.
\end{tabular}

Sesi workshop dimulai dengan presentasi proyek desain botol parfum dari tiap mahsiswa/peserta. Bentuk proyek desain adalah perseorangan dan bukan kelompok. Proyek desain ini telah berjalan selama 2 minggu perkuliahan sebelumnya dimana setiap peserta diminta untuk memilih sesuatu hewan, lalu mengamati bentuk, warna, dan karakteristik hewan tersebut dan menjadikannya menjadi panduan dalam mendesain botol parfum. Kegiatan desain seperti ini disebut sebagai zoomorphic product design, yang menurut Duncan et al (2015) adalah bentuk-bentuk benda dan produk yang dibuat oleh manusia yang memiliki bentuk dan penampakan suatu binatang.

Sesi dilanjutkan dengan kuliah dan presentasi mengenai desain produk berkelanjutan oleh penulis pertama yang diisi pula dengan materi tentang life cycle assessment dan strategi desain yang berwawasan lingkungan. Lalu, mahasiswa diperkenalkan dengan metodologi Okala disertai dengan pembahasan sekilas mengenai poin-poin strategi yang ada didalamnya. Penulis pertama lalu meminta peserta workshop untuk menerapkan strategi Okala pada proyek mereka masing-masing. Peserta lalu diberikan soft copy dan hard copy Okala untuk mereka pilih dan terapkan sesuai relevansinya pada proyek desain mereka. Tiap peserta lalu diberikan waktu untuk menjelaskan pemikiran mereka dalam bentuk poin-poin dan/atau sketsa cepat pada selembar kertas berukuran A3 yang disebarkan. Setelah selesai, sesi workshop pun ditutup oleh dosen yang bertanggung jawab.

Perlu diperhatikan bahwa sebelum dilakukan workshop ini, peserta belum diberitahu untuk mempertimbangkan aspek desain produk berkelanjutan sebelum memulai dan saat mengerjakan proyek desain botol parfum tersebut. Peserta baru diminta untuk menerapkan strategi Okala setelah dilakukan kuliah mengenai desain produk berkelanjutan dan pengenalan Okala.

\section{HASIL DAN PEMBAHASAN}

Berikut ini merupakan salah satu karya peserta sebelum mengikuti workshop seperti 
ditunjukkan Gambar 2 dan sesudah mengikuti workshop seperti ditunjukkan Gambar 3.

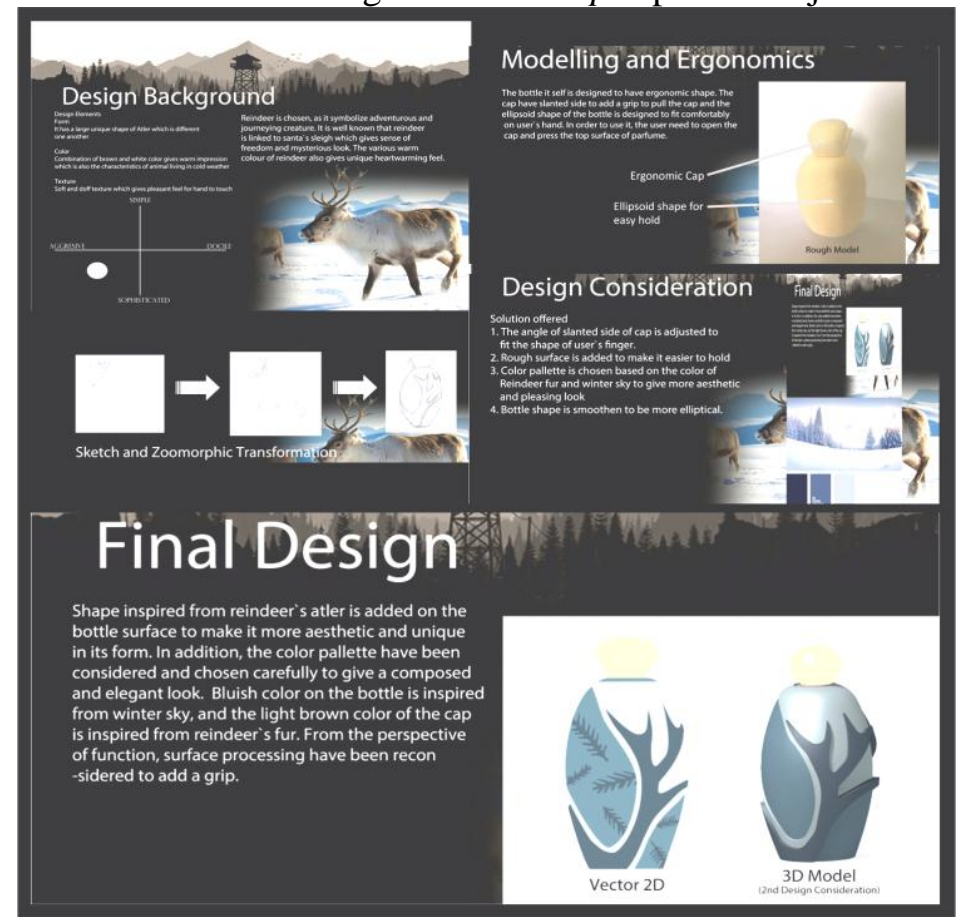

Gambar 2. Desain botol parfum zoomorphic rusa kutub karya salah seorang peserta sebelum menerapkan strategi Okala oleh salah satu peserta

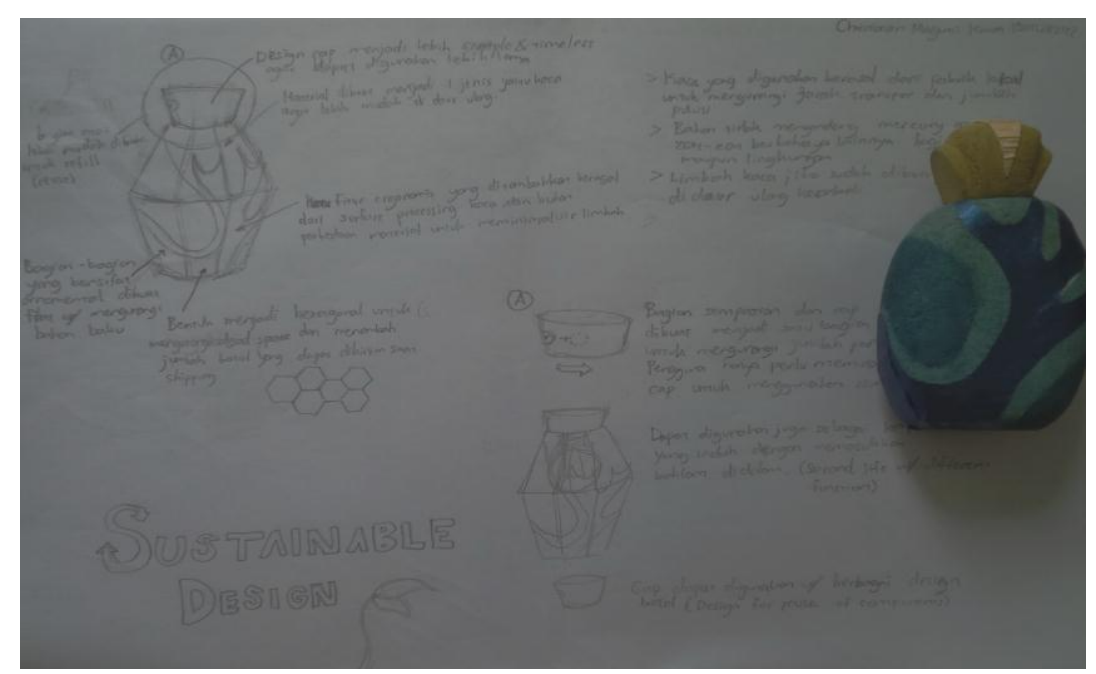

Gambar 3. Deskripsi dan sketsa pengembangan desain botol parfum zoomorphic rusa kutub dengan menerapkan strategi Okala oleh salah satu peserta

Seperti tertera dalam Gambar 2 dan Gambar 3 di atas, peserta mengimplementasikan beberapa butir strategi Okala pada proyek desainnya. Dengan implementasi Okala, peserta secara aktif melakukan perubahan desain, baik bentuk dan pemilihan material botol parfum, sehingga terjadi perubahan dalam desain final botol parfum. Dalam Gambar 4, penulis mengumpulkan pilihan strategi yang diimplementasikan peserta secara keseluruhan. 


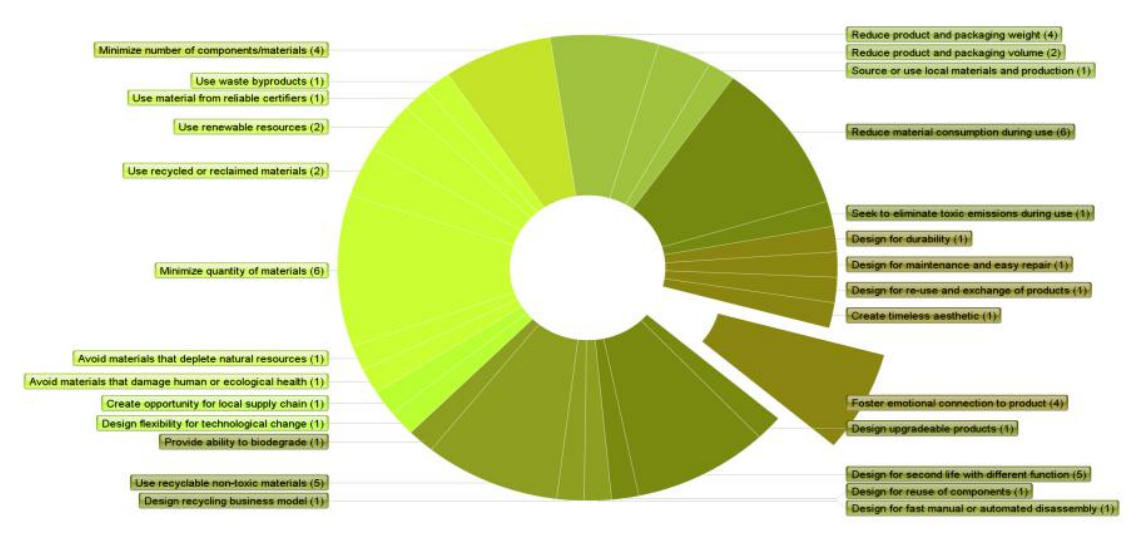

Gambar 4. Rangkuman butir-butir strategi Okala yang diterapkan peserta pada proyek desain botol parfum

Dari hasil yang didapat dan dikumpulkan, tidak seluruh butir-butir strategi yang terdapat di dalam Okala dipilih untuk diterapkan oleh peserta pada proyek desain mereka. Hal ini dapat disebabkan oleh dua hal yaitu: tidak relevannya butir-butir tertentu pada proyek desain mereka dan/atau dikarenakan pemahaman peserta terhadap butir-butir tertentu yang belum optimal.

Sebanyak 6 orang partisipan memilih menerapkan strategi mengurangi kuantitas material (minimize quantity of material)yang dipakai untuk proyek botol parfum mereka masing-masing. Beberapa solusi yang mereka tawarkan diantaranya, mengecilkan satu atau beberapa bagian botol, mengubah ukuran botol secara keseluruhan menjadi lebih kecil dan memberi coakan (fillet) pada permukaan botol. Solusi tersebut diupayakan untuk mengurangi kuantitas material yang diperlukan untuk memproduksi botol parfum. Solusi sistem refill juga cukup populer di kalangan peserta, yaitu dengan opsi menukarkan kontainer cairan parfum yang sudah habis dengan yang baru, tanpa membuang botol parfum secara keseluruhan dan membelinya lagi. Ini adalah upaya mengurangi konsumsi material saat penggunaan (reduce material consumption during use) yang dipilih oleh 6 orang peserta. Sebanyak 6 peserta juga menganggap strategi mengurangi jumlah komponen (minimize number of components/material) pada botol parfum mereka merupakan solusi yang relevan yaitu dengan menggunakan material yang homogen pada produk botol mereka. Pemilihan material cairan parfum terbarukan yang ramah lingkungan (use recycable non-toxic materials) dipilih oleh sebanyak 5 orang peserta.

Proyeksi akhir siklus hidup produk menjadi perhatian 5 orang peserta yang memilih untuk menerapkan opsi strategi fungsi produk kedua, yaitu ketika produk mencapai akhir masa hidup produknya, produk dapat dialihfungsikan menjadi produk yang berfungsi sama sekali berbeda. Semisal botol parfum yang dapat diubah menjadi tempat pensil setelah cairan parfum habis.

Satu butir strategi Okala lainnya yaitu mempererat hubungan emosional konsumer dengan produk (foster emotional attachment to product) diterapkan oleh 4 orang peserta melalui pilihan kustomisasi produk botol, seperti pilihan warna dan bentuk yang dapat semakin mendekatkan konsumen dengan produk botol parfum mereka.

Dengan mempertimbangkan kurun waktu yang cukup singkat mulai dari penjelasan dan penerapan pada proyek desain botol yang sedang berjalan, setiap peserta dapat mengimplementasikan strategi-strategi yang terdapat dalam Okala Eco-design Strategy Wheel dengan cukup mudah. Sebagian besar peserta mendapat gambaran desain produk yang berkelanjutan melalui strategi yang diberikan Okala. Mayoritas peserta berpendapat bahwa beberapa butir dari Okala tidak relevan dengan proyek mereka, khususnya hal-hal yang sangat terkait dengan manufaktur, misalnya jejak karbon (carbon footprint) yang dihasilkan pada saat proses produksi dan pertimbangan mengurangi volume produk dan kemasannya untuk meningkatkan efektivitas jumlah produk yang dapat didistribusikan dalam waktu yang 
bersamaan. Hal ini bermuara pada tahap proyek yang masih dalam tahap desain, belum dalam tahap produksi riil/manufaktur).

\section{SIMPULAN}

Dari hasil analisa workshop dan penelitian yang telah dilaksanakan, dapat diambil kesimpulan bahwa Okala sebagai metodologi life cycle assessment merupakan perangkat yang efektif untuk peserta (mahasiswa Product Design Engineering) dalam membantu memperkirakan dampak produk yang dirancang. Perangkat Okala cenderung dapat dipahami dalam kurun waktu yang singkat dan implementasinya pada proyek desain tidak memakan waktu yang lama. Okala dapat menjadi perangkat pendukung yang mumpuni dalam pengajaran desain produk berkelanjutan (sustainable product design) dalam ranah pendidikan desain. Studi lanjut atau studi perbandingan yang lebih signifikan perlu dilakukan di antara proyek desain tanpa bantuan metode Okala dan dengan Okala ketika proses desain berada pada tahap final.

\section{DAFTAR PUSTAKA}

Duncan, N., Yu, L., Yeung, S., Terzopoulos, D. (2015). Zoomorphic Design. ACM Transactions on Graphics, 34(4), 1-13.

Findeli, A. (2001). Rethinking design education for the 21st century: theoretical, methodological, and ethical discussion. Design Issues, 17(1), 5-17.

ICSID. 1987. ICSID Model Code of Professional Conduct for Designers. Essen: International Council of Societies of Industrial Design.

ICSID. 2001. ICSID Seoul 2001 Industrial Designers Declaration. Seoul: International Council of Societies of Industrial Design.

Papanek, V. J. (1971). Design for the real world: human ecology and social change. London: Thames \& Hudson.

Park, M. (2010). Green is not the only colour that matters: Teaching sustainable design and research trajectories. Connected 2010 - 2nd International Conference on Design Education, Sydney, Australia.

Ramirez, M. (2005), 'Ecological Sustainability Integration in Australian Industrial Design', in Futureground: 2004. International Conference of the Design Research Society, Melbourne.

Ramirez, M. (2007). Sustainability integration in industrial design education: a worldwide survey. Connected 2007 International Conference on Design Education, Sydney, Australia. July 2007. 